\title{
Food and Feeding Habits of Aquaculture Candidate a Potential Crustacean of Pacific White Shrimp Litopenaeus Vannamei, South East Coast of India
}

\author{
Varadharajan D* and Pushparajan N \\ Faculty of Marine Sciences, Centre of Advanced Study in Marine Biology, Annamalai University, Tamil Nadu, India
}

\begin{abstract}
The foods are very essential of any organisms, basically its needs for growth, existence and culture aspects. Study of food and feeding habits of $L$. vannamei have manifold importance in fishery biology. The shrimp aquaculture has appeared in the last two decades primarily as a live holding and marketing strategy, to bring certainty to supply of high value $L$. vannamei. Still a number of species of marine shrimp are edible, the biggest and most highly esteemed species suitable for coastal aquaculture. Shrimp farmers also need to know how much feed their livestock have actually consumed but this can be difficult to judge and also the successful farming a detailed knowledge about the food and feeding habit is essential. The analysis of gut contents of $L$. vannamei provides information about particular shrimp in the ecosystem.
\end{abstract}

Keywords: World history of food and feeding; White leg shrimp, Original farming technology

\section{Introduction}

The penaeid shrimp culture has developed fast over the last three decades to become an important economic activity in many countries. The study of food and feeding and assimilation are of fundamental importance in understanding the rate of growth, population concentration, gonadial maturation and other metabolic activities. Mostly shrimps have been described as omnivorous scavengers and detritus feeders. Feed management is an important factor in aquaculture, excess feed generates some problems for example reduces survival and growth rates of the cultivated organisms [1,2]. Feeds used in culture are also concerned about nutrient loss through leaching. Because, the feeding habits of shrimp, food is not rapidly consumed. Ingestion rates quantify the amount of food ingested by the cultivated animals. The cultured candidate important species are Penaeus indicus, P. monodon, P. semisulcatus $P$. merguiensis, Metapenaeus affinis, $M$. dobsoni, M. ensis, M. monoceros and M. brevicornis are also potential species that can be grown in aquaculture industries. Two among these species are still more considered to be the best for commercial culture. They are Indian white shrimp Penaeus indicus and tiger shrimp Penaeus monodon. Similarly another potential candidate species that is flooding international market is the White leg shrimp, Penaeus vannamei [3-5]. Even though the authority of government has not so far given sanctions to culture Litopenaeus vannamei in the country, many countries have already started to culture this species [6]. It has confronted several of the developmental problems in this relatively short period and concerns over environmental impacts. In the present study of food and feeding habits of L. vannamei have manifold importance in fishery biology and aquaculture potential of this shrimp, there is the need to provide information on its food and feeding habits. Since the successful farming a detailed knowledge about the food and feeding habit is essential. The nature of food depends to a great extent upon the nature of environment. Detailed studies have been made in India on food and feeding habits of Metapenaeus dobsoni [7], Penaeus monodon [8] and P. semisulcatus [9] have mentioned the food of some penaeid prawns. L. vannamei is one among the important penaeid species utilized for prawn culture practices. There is very good scope for this species to be taken up for intensive, semi intensive and mass scale culture practices in India and other countries. In the present study used as may enables to select suitable food material for the L. vannamei for cultivable purposes.

\section{Materials and Methods}

The samples of L.vannamei collected from culturing shrimp ponds from near in Vellar estuary from Parangipettai coast. After collection, the shrimps were stored in ice boxes and the stomachs were removed and fixed in $10 \%$ buffered formalin and were analysed to study the food and feeding habits of this species. It is very difficult to identify the food items specie wise due to the nibbling action of mandibles on the food and mastigation of food inside the stomach by the action of gastric mill. The stomach contents were later analyzed in the laboratory after dissecting the alimentary system and different components of the guts were recorded. They were split open by a pair of scissors and emptied in a petri dish. The content was examined with the help of zoom dissection binocular microscope. The food items were identified up to the family level wherever possible, the assumed prey material was sorted and preserved in $70 \%$ alcohol for further identification [10,11]. In order to help the interpretation of the stomach contents analysis, the feeding behavior of the shrimp species under study were occasionally observed and recorded in their natural environment during the field missions $[12,13]$. For identification of phytoplankton, identification manual of NIO (2004) was used [14]. Identify the zooplankton by using the references of Kasthurirangan (1963) [15] and Wickstead (1965) [16] The polychaetes were identified by using the handbooks of Fauvel (1927) [17] and Berkeley (1952) [18] and other preys were identified by using standard manuals.

After identification each food category was expressed as percentage of all the stomachs examined according to the formula of Percentage occurrence $=(b / n) \times 100$

*Corresponding author: Varadharajan D, Faculty of Marine Sciences, Centre of Advanced Study in Marine Biology, Annamalai University, TamilNadu, India, E-mail: heartvaradhan@gmail.com

Received August 23, 2012; Accepted November 10, 2012; Published Novembe 20, 2012

Citation: Varadharajan D, Pushparajan N (2013) Food and Feeding Habits of Aquaculture Candidate a Potential Crustacean of Pacific White Shrimp Litopenaeus Vannamei, South East Coast of India. J Aquac Res Development 4:161 doi:10.4172/2155-9546.1000161

Copyright: @ 2013 Varadharajan D, et al. This is an open-access article distributed under the terms of the Creative Commons Attribution License, which permits unrestricted use, distribution, and reproduction in any medium, provided the original author and source are credited. 
Citation: Varadharajan D, Pushparajan N (2013) Food and Feeding Habits of Aquaculture Candidate a Potential Crustacean of Pacific White Shrimp Litopenaeus Vannamei, South East Coast of India. J Aquac Res Development 4:161 doi:10.4172/2155-9546.1000161

Page 2 of 5

Where $b$ is the number of shrimp stomachs that had a food item and $\mathrm{n}$ is the number of shrimp stomachs dissected, excluding those that were empty. The food item with the highest value was taken as the most important one. All the statistical analysis was performed by using SPSS 16 software, particularly Box Plot Method.

\section{Results}

The food items found in the examined both males and females guts were grouped into twelve categories namely Phytoplankton, Zooplankton, Crustacean, Amphipods, Isopods, Polychaetes, Nematodes, Mollusca, Detritus, Mud, Miscellaneous and Supplementary feed. The gut contents of male shrimp $L$. vannamei phytoplankton contribution were maximum and polychaetes were minimum in $70-80 \mathrm{~mm}$ sizes. The gut contents of L. vannamei were in the following order; Phytoplankton $(14.6 \%)>$ Zooplankton (12.5\%) $>$ Miscellaneous (11.3\%) $>$ Amphipods (8.6\%) $>$ Mud $(8.5 \%)>$ Detritus $(7.9 \%)>$ Supplementary feed $(7.9 \%)>$ Crustacean $(7.6 \%)$ $>$ Isopods $(6.4 \%)>$ Nematodes $(5.2 \%)>$ Mollusca $(4.9 \%)>$ Polychaetes (4.6\%). The gut contents of male shrimp L. vannamei phytoplankton contribution were maximum and polychaetes were minimum in 90$100 \mathrm{~mm}$ sizes. The gut contents of $L$. vannamei were in the following order; Phytoplankton $(13.9 \%)>$ Zooplankton $(11.8 \%)>$ Miscellaneous $(10.0 \%)>$ Supplementaryfeed $(8.5 \%)>\operatorname{Isopods}(8.5 \%)>\operatorname{Detritus}(8.4 \%)>\operatorname{Mud}(8.3 \%)$ $>$ Amphipods $(7.6 \%)>$ Nematodes $(6.3 \%)>$ Crustacean $(5.8 \%)>$ Mollusca $(5.7 \%)>$ Polychaetes $(5.2 \%)$. The gut contents of male shrimp L.vannamei crustacean contribution were maximum and polychaetes were minimum in 110-120 mm sizes. The gut contents of $L$. vannamei were in the following order; Crustacean (12.6) > Miscellaneous (10.7) > Phytoplankton (10.5\%) $>$ Supplementary feed (9.7\%) > Amphipods (9.5\%) > Zooplankton (8.5\%) $>$ Isopods (7.9\%) > Detritus (7.5\%) > Mud (7.3\%) > Nematodes (5.7\%) >
Mollusca (5.3\%) > Polychaetes (4.8\%). The gut contents of male shrimp $L$. vannamei miscellaneous contribution were maximum and mollusca were minimum in 130-140 mm sizes. The gut contents of L. vannamei were in the following order; Miscellaneous (11.9\%) > Supplementary feed (11.3\%) $>$ Detritus $(10.5 \%)>$ Crustacean $(10.5 \%)>$ Phytoplankton $(9.5 \%)>\mathrm{Mud}$ $(9.5 \%)>$ Zooplankton $(7.3 \%)>$ Amphipods $(7.1 \%)>$ Isopods $(6.7 \%)$ $>$ Nematodes $(6.3 \%)>$ Polychaetes $(5.4 \%)>$ Mollusca $(4.3 \%)$. The gut contents of male shrimp L. vannamei supplementary feed contribution were maximum and mollusca were minimum in 150-160 $\mathrm{mm}$ sizes. The gut contents of $L$. vannamei were in the following order; Supplementary feed $(13.4 \%)>$ Miscellaneous $(10.2 \%)>$ Amphipods $(9.8 \%)>$ Crustacean $(8.7 \%)>$ Nematodes $(8.1 \%)>$ Mud $(8.0 \%)>$ Phytoplankton $(7.8 \%)$ $>$ Polychaetes $(7.3 \%)>$ Isopods $(7.2 \%)>$ Detritus $(7.1 \%)>$ Zooplankton $(6.8 \%)>$ Mollusca (5.6\%). The gut contents of male shrimp L. vannamei supplementary feed contribution were maximum and zooplanktons were minimum in 170-180 mm sizes. The gut contents of L. vannamei were in the following order; Supplementary feed (12.8\%) > Miscellaneous (9.8\%) > Crustacean $(9.5 \%)>$ Detritus $(9.3 \%)>$ Nematodes $(8.6 \%)>$ Amphipods $(8.6 \%)>$ Isopods $(8.3 \%)>$ Polychaetes $(8.1 \%)>$ Mollusca $(7.4 \%)>$ Phytoplankton $(6.3 \%)>$ Mud $(6.2 \%)>$ Zooplankton $(5.1 \%)$. The gut contents of male shrimp L. vannamei supplementary feed contribution were maximum and zooplanktons were minimum in 190-200 mm sizes. The gut contents of L. vannamei were in the following order; Supplementary feed $(13.6 \%)>$ Crustacean $(10.8 \%)>$ Mud $(10.6 \%)$ $>$ Miscellaneous $(10.1 \%)>$ Isopods $(8.1 \%)>$ Amphipods $(7.9 \%)>$ Nematodes $(7.5 \%)>$ Detritus $(7.2 \%)>$ Mollusca $(6.9 \%)>$ Polychaetes $(6.7 \%)>$ Phytoplankton $(5.9 \%)>$ Zooplankton $(4.7 \%)$ were observed in different size group males of $P$. vannamei respectively (Table 1 ).

Similarly the gut contents of female shrimp L. vannamei

\begin{tabular}{|c|c|c|c|c|c|c|c|c|c|}
\hline \multirow[t]{2}{*}{ S:No } & \multirow[t]{2}{*}{ Prey items } & \multicolumn{8}{|c|}{ Size groups $(\mathrm{mm})$} \\
\hline & & $70-80$ & $90-100$ & $110-120$ & $130-140$ & $150-160$ & $170-180$ & $190-200$ & Average \\
\hline 1 & Phytoplankton & 14.6 & 13.9 & 10.5 & 9.5 & 7.8 & 6.3 & 5.9 & 9.78 \\
\hline 2 & Zooplankton & 12.5 & 11.8 & 8.5 & 7.3 & 6.8 & 5.1 & 4.7 & 8.10 \\
\hline 3 & Crustaceans & 7.6 & 5.8 & 12.6 & 10.2 & 8.7 & 9.5 & 10.8 & 9.31 \\
\hline 4 & Amphipods & 8.6 & 7.6 & 9.5 & 7.1 & 9.8 & 8.6 & 7.9 & 8.44 \\
\hline 5 & Isopods & 6.4 & 8.5 & 7.9 & 6.7 & 7.2 & 8.3 & 8.1 & 7.58 \\
\hline 6 & Polychaetes & 4.6 & 5.2 & 4.8 & 5.4 & 7.3 & 8.1 & 6.7 & 6.01 \\
\hline 7 & Nematodes & 5.2 & 6.3 & 5.7 & 6.3 & 8.1 & 8.6 & 7.5 & 6.81 \\
\hline 8 & Mollusca & 4.9 & 5.7 & 5.3 & 4.3 & 5.6 & 7.4 & 6.9 & 5.72 \\
\hline 9 & Detritus & 7.9 & 8.4 & 7.5 & 10.5 & 7.1 & 9.3 & 7.2 & 8.27 \\
\hline 10 & Mud & 8.5 & 8.3 & 7.3 & 9.5 & 8 & 6.2 & 10.6 & 8.34 \\
\hline 11 & Miscellaneous & 11.3 & 10 & 10.7 & 11.9 & 10.2 & 9.8 & 10.1 & 10.57 \\
\hline 12 & Supplementary feeds & 7.9 & 8.5 & 9.7 & 11.3 & 13.4 & 12.8 & 13.6 & 11.02 \\
\hline
\end{tabular}

Table 1: Percentage of dietary composition of different food items in different size groups of male L.vannamei.

\begin{tabular}{|c|c|c|c|c|c|c|c|c|c|}
\hline \multirow[t]{2}{*}{ S:No } & \multirow[t]{2}{*}{ Prey items } & \multicolumn{8}{|c|}{ Size groups(mm) } \\
\hline & & $70-80$ & $90-100$ & $110-120$ & $130-140$ & $150-160$ & $170-180$ & $190-200$ & Average \\
\hline 1 & Phytoplankton & 13.7 & 10.6 & 9.4 & 10.3 & 6.7 & 7.1 & 4.8 & 8.94 \\
\hline 2 & Zooplankton & 12.1 & 9.8 & 7.2 & 6.5 & 7.3 & 6.9 & 4.6 & 7.77 \\
\hline 3 & Crustaceans & 6.5 & 5.7 & 11.6 & 8.7 & 10.9 & 8.5 & 11.5 & 9.05 \\
\hline 4 & Amphipods & 9.3 & 7.2 & 8.1 & 6.3 & 7.6 & 6.8 & 8.5 & 7.68 \\
\hline 5 & Isopods & 5.3 & 8.1 & 7.5 & 8.3 & 7.9 & 7.6 & 8.1 & 7.54 \\
\hline 6 & Polychaetes & 3.7 & 6.3 & 5.8 & 6.1 & 7.2 & 8.5 & 7.3 & 6.41 \\
\hline 7 & Nematodes & 4.6 & 5.7 & 6.3 & 5 & 6.1 & 8.6 & 5.3 & 5.94 \\
\hline 8 & Mollusca & 5.2 & 6.8 & 5.7 & 4.5 & 5.8 & 7.3 & 7.6 & 6.12 \\
\hline 9 & Detritus & 10.3 & 9.7 & 8.1 & 9.3 & 10.7 & 8.5 & 8.1 & 9.24 \\
\hline 10 & Mud & 7.8 & 10 & 9.7 & 8.7 & 9.2 & 6.8 & 11.3 & 9.07 \\
\hline 11 & Miscellaneous & 12.8 & 10.5 & 11.7 & 13.8 & 9.8 & 12.1 & 10.2 & 11.55 \\
\hline 12 & Supplementary feeds & 8.7 & 9.6 & 8.9 & 12.5 & 10.8 & 11.3 & 12.7 & 10.64 \\
\hline
\end{tabular}

Table 2: Percentage of dietary composition of different food items in different size groups of female L.vannamei. 
Citation: Varadharajan D, Pushparajan N (2013) Food and Feeding Habits of Aquaculture Candidate a Potential Crustacean of Pacific White Shrimp Litopenaeus Vannamei, South East Coast of India. J Aquac Res Development 4:161 doi:10.4172/2155-9546.1000161

phytoplankton contributions were maximum and polychaetes were minimum in $70-80 \mathrm{~mm}$ sizes. The gut contents of L. vannamei were in the following order; Phytoplankton (13.7\%) > Miscellaneous $(12.8 \%)$ $>$ Zooplankton (12.1\%) > Detritus (10.3\%) > Amphipods $(9.3 \%)$ $>$ Supplementary feed $(8.7 \%)>$ Mud $(7.8 \%)>$ Crustacean $(6.5 \%)>$ Isopods $(5.3 \%)>$ Mollusca $(5.2 \%)>$ Nematodes $(4.6 \%)>$ Polychaetes (3.7\%). The gut contents of female shrimp L. vannamei phytoplankton contributions were maximum and nematodes were minimum in 90 $100 \mathrm{~mm}$ sizes. The gut contents of $L$. vannamei were in the following order; Phytoplankton (10.6\%) > Miscellaneous (10.5\%) > Mud (10.0\%) $>$ Zooplankton $(9.8 \%)>$ Detritus $(9.7 \%)>$ Supplementary feed $(9.6 \%)$ $>$ Isopods $(8.1 \%)>$ Amphipods (7.2\%) $>$ Mollusca (6.8\%) $>$ Polychaetes $(6.3 \%)>$ Crustacean $(5.7 \%)>$ Nematodes $(5.7 \%)$. The gut contents of female shrimp L. vannamei miscellaneous contributions were maximum and mollusca were minimum in $110-120 \mathrm{~mm}$ sizes. The gut contents of $L$. vannamei were in the following order; Miscellaneous $(11.7 \%)>$ Crustacean $(11.6 \%)>$ Phytoplankton $(11.0 \%)>\mathrm{Mud}$ $(9.7 \%)>$ Supplementary feed $(8.9 \%)>$ Detritus $(8.1 \%)>$ Amphipods $(8.1 \%)>$ Isopods $(7.5 \%)>$ Zooplankton $(7.2 \%)>$ Nematodes $(6.3 \%)$ $>$ Polychaetes $(5.8 \%)>$ Mollusca $(5.7 \%)$. The gut contents of female shrimp L. vannamei miscellaneous contributions were maximum and mollusca were minimum in $130-140 \mathrm{~mm}$ sizes. The gut contents of L. vannamei were in the following order; Miscellaneous (13.8\%) > Supplementary feed $(12.5 \%)>$ Phytoplankton $(10.3 \%)>$ Detritus $(9.3 \%)$ $>$ Crustacean $(8.7 \%)>$ Mud $(8.7 \%)>$ Isopods $(8.3 \%)>$ Zooplankton $(6.5 \%)>$ Amphipods $(6.3 \%)>$ Polychaetes $(6.1 \%)>$ Nematodes $(5.0 \%)$ $>$ Mollusca (4.5\%). The gut contents of female shrimp L. vannamei crustacean contributions were maximum and mollusca were minimum in $150-160 \mathrm{~mm}$ sizes. The gut contents of $L$. vannamei were in the following order; Crustacean $(10.9 \%)>$ Supplementary feed $(10.8 \%)>$ Detritus $(10.7 \%)>$ Miscellaneous $(9.8 \%)>$ Mud $(9.2 \%)>$ Isopods $(7.9 \%)$ $>$ Amphipods (7.6\%) > Zooplankton (7.3\%) > Polychaetes $(7.2 \%)>$ Phytoplankton $(6.7 \%)>$ Nematodes $(6.1)>$ Mollusca $(5.8 \%)$. The gut contents of female shrimp L. vannamei miscellaneous contributions were maximum and amphipods were minimum in $170-180 \mathrm{~mm}$ sizes. The gut contents of $L$. vannamei were in the following order; Miscellaneous $(12.1 \%)>$ Supplementary feed $(11.3 \%)>$ Crustacean $(8.5 \%)>$ Detritus $(8.5 \%)>$ Polychaetes $(8.5 \%)>$ Nematodes $(8.6 \%)>$ Isopods $(7.6 \%)$ $>$ Mollusca $(7.3 \%)>$ Phytoplankton $(7.1 \%)>$ Zooplankton $(6.9 \%)>$ Mud (6.8\%) > Amphipods (6.8\%). The gut contents of female shrimp L. vannamei supplementary feed contributions were maximum and zooplanktons were minimum in $190-200 \mathrm{~mm}$ sizes. The gut contents of L. vannamei were in the following order; Supplementary feed $(12.7 \%)>$ Crustacean $(11.5 \%)>$ Mud $(11.3 \%)>$ Miscellaneous $(10.2 \%)$ $>$ Amphipods $(8.5 \%)>$ Detritus $(8.1 \%)>$ Isopods $(8.1 \%)>$ Mollusca $(7.6 \%)>$ Polychaetes $(7.3 \%)>$ Nematodes $(5.3 \%)>$ Phytoplankton $(4.8 \%)>$ Zooplankton $(4.6 \%)$ were observed in different size group females of $P$. vannamei respectively (Table 2).

The showed graphs are Box Plot, its combines the minimum and maximum values of different size groups of $L$. vannamei in prey compositions. The analyses gut contents of 70-80 $\mathrm{mm}$ size of male L.vannamei, it was observed prey compositions to the values the distribution is normal, since the mean and median should be similar. As well as followed the female L. vannamei was observed values of distribution are shifted to the right, the mean should be greater than the median (Figure 1). $90-100 \mathrm{~mm}$ sizes of male to the values the distribution is normal, since the mean and median should be similar. However, the female L.vannamei was observed values of distribution are shifted to the right, the mean should be greater than the median (Figure 2). 110-120 $\mathrm{mm}$ sizes of male to the values the distribution is

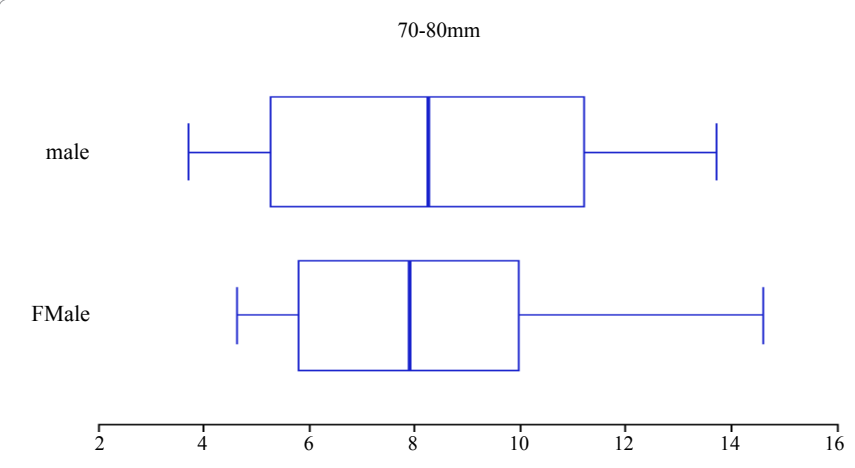

Figure 1: The variations of the prey items in $(70-80 \mathrm{~mm})$ male and female of L.vannamei.

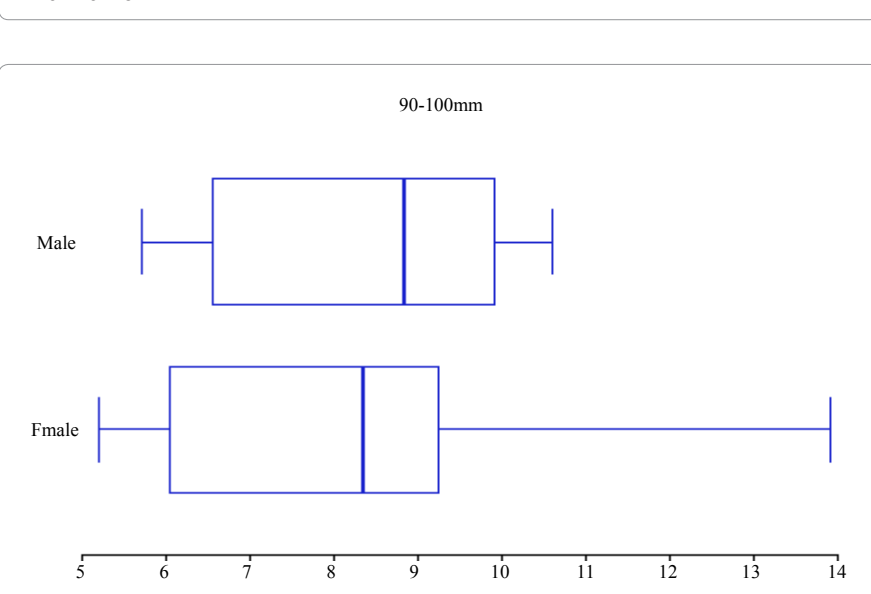

Figure 2: The variations of the prey items in $(90-100 \mathrm{~mm})$ male and female of L.vannamei.

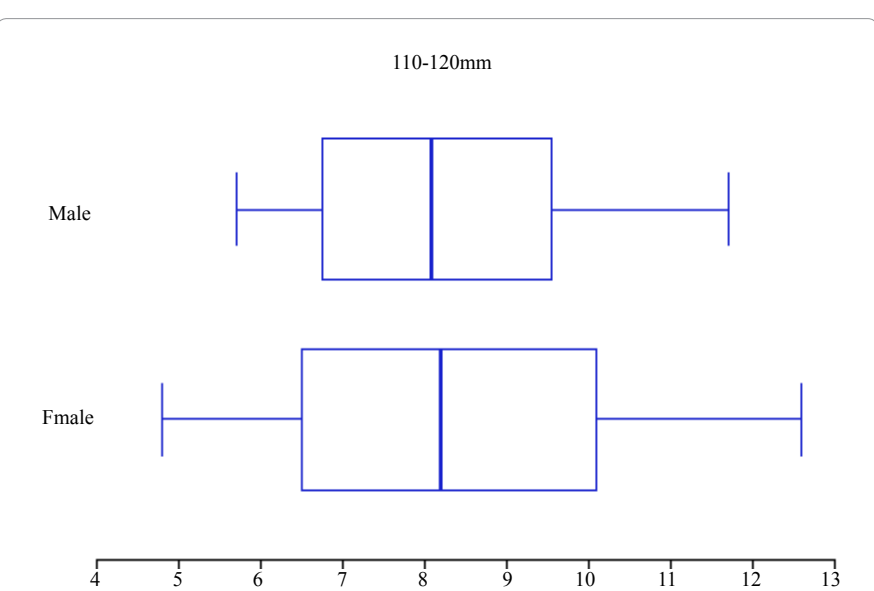

Figure 3: The variations of the prey items in $(110-120 \mathrm{~mm})$ male and female of L.vannamei.

shifted to the right, the mean should be greater than the median, since the female too values the distribution is normal, mean and median should be similar (Figure 3). 130-140 mm sizes of male to the values the distribution is shifted to the right, the mean should be greater than the median, since the female also values the distribution is shifted to the left, the mean should be less than median (Figure 4). 150-160 mm sizes of male to the values the distribution is shifted to the left, the mean should be less than median, with same values find the females (Figure 5). 170-180 mm 
$130-140$
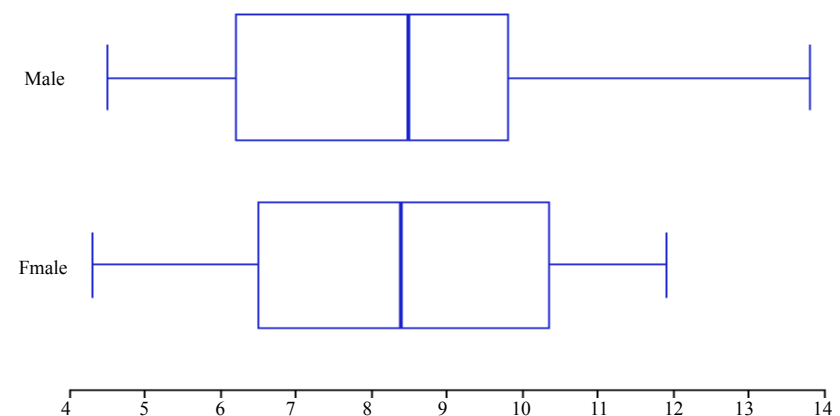

Figure 4: The variations of the prey items in $(130-140 \mathrm{~mm})$ male and female of L.vannamei.

$150-160 \mathrm{~mm}$

Male

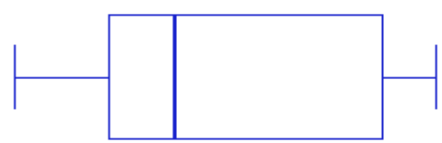

Fmale

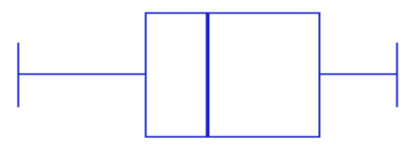

5

Figure 5: The variations of the prey items in $(150-160 \mathrm{~mm})$ male and female of L.vannamei.

$170-180 \mathrm{~mm}$

Male
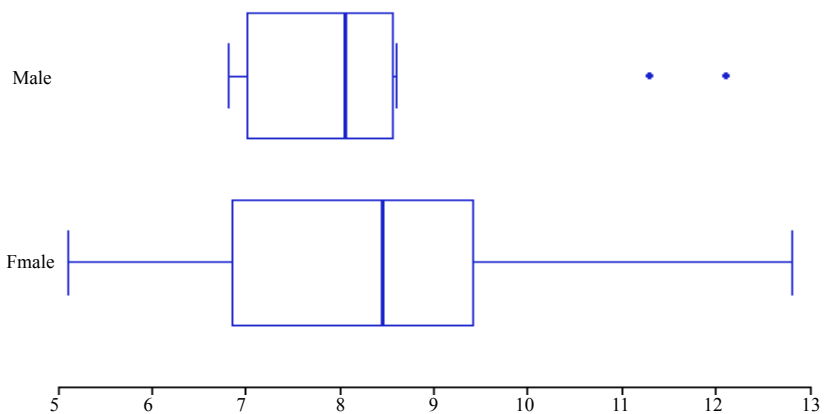

Figure 6: The variations of the prey items in $(170-180 \mathrm{~mm})$ male and female of L.vannamei.

sizes of the females to the values the distribution is shifted to the right, the mean should be greater than the median, since the males, outliers show to the extreme levels of the values (Figure 6). 190-200 mm sizes of males to the values the distribution is normal, mean and median should be similar, since the females the distribution of values is shifted to the right, the mean should be greater than the median (Figure 7).

\section{Discussion}

The fastest growing forms of aquaculture, now accounts for one- third of the shrimp produced globally. It is a rich source of animal protein and its culture is an efficient protein food production system from aquatic environment. The main role of shrimp culture is its contribution in improving the nutritional standards of the people. The Pacific White shrimp Litopenaeus vannamei has become the main crustacean species produced through aquaculture, with production exceeding that of the black tiger shrimp Penaeus monodon [3-5]. The basic principle of shrimp culture system is the stocking of various fast-growing, compatible species of shrimp with complementary feeding habits to utilize efficiently the natural food present at different ecological niches in the pond for maximising shrimp production [19]. Natural resources can be used as culture systems and organisms to be cultured are stocked in the water body. Limiting for growth here is the available food supply by natural sources, commonly shrimp feeding on pelagic algae or benthic animals, such as other crustaceans and Mollusca. Thomas (1972) indicated that the most common food items of coastal and estuarine shrimps were small crustaceans, algae, small mollusc and detritus, while the marine shrimps subsisted mainly on small crustaceans [8]. Rao (1988) stated that the food of shrimps in the inshore waters comprised of mainly smaller crustaceans, phytoplankton, zooplankton, polychaetes, detritus, fishes, sand, crustaceans and miscellaneous [20]. In the present study both male and females, the following food items noticed in the guts in order of abundance were L. vannamei phytoplankton, zooplankton, nematodes, polychaetes, detritus, crustacean, amphipods, isopods, mud, miscellaneous and supplementary feed [21].

In the present study the food items like crustaceans, mud, detritus, miscellaneous and supplementary feed were consumed at all times of the months [9]. The quantity of mud and sand in the guts was negligible and appears to be accidental inclusions as a result of the bottom feeding habit of the species. Mud was the dominant food item, although a relatively low quantity was consumed in April and May. Menon (1951) stated that food of shrimps consisted of detritus both animal and plant that accumulate at the bottom of their habitat [7]. Pillay (1952) observed that the detritus and sand grains as the most common contents of stomachs of Leander styliferus from West Bengal, India [12]. Detritus and miscellaneous were the next predominant items and their presence in the diet was relatively uniform throughout the period. Polychaetes, nematodes were found in all the months, being most abundant in August and hence it can be considered as one of the regular items of food of the species. The pattern of consumption of the mollusc, amphipods and isopods was almost similar. The presence of all other food items showed irregular fluctuations. The analysis of food with respect to size revealed that detritus, mud, miscellaneous, crustaceans and plankton

\section{$190-200 \mathrm{~mm}$}
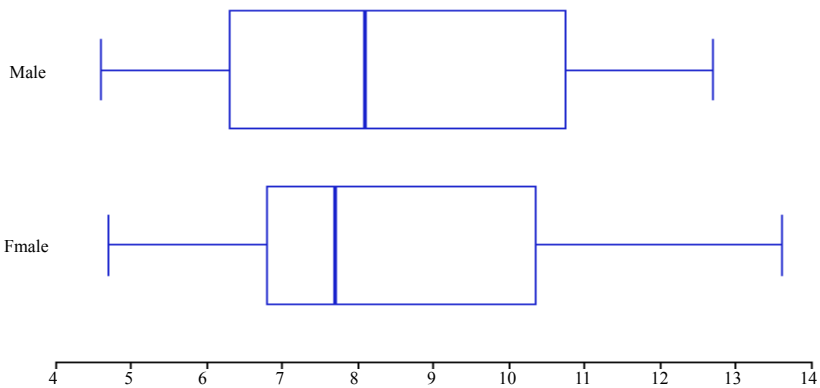

Figure 7: The variations of the prey items in $(190-200 \mathrm{~mm})$ male and female of L.vannamei. 
Citation: Varadharajan D, Pushparajan N (2013) Food and Feeding Habits of Aquaculture Candidate a Potential Crustacean of Pacific White Shrimp Litopenaeus Vannamei, South East Coast of India. J Aquac Res Development 4:161 doi:10.4172/2155-9546.1000161

were the main items of food in all size groups. George (1974) stated that juvenile M. monoceros from Cochin backwaters is carnivorous and shows preferences for small crustaceans [22]. The difference in gut contents and food preference was mainly due to availability within the ambit of selectivity. This observation agrees with the statement of Tiews et al. (1968) [23]. This feeding habit showed their adaptability in unfavorable conditions of non availability of other preferred food items. In the present study the food and feeding habits both males and females of L. vannamei in the pond culturing conditions that they are omnivorous for young stages day by day increasing size and growth there will be changing feeding strategies for animal origin of feeds. The change in diet of the species could be due to a low availability of its preferred shrimp food in the cultured habitat. These analyses show that there are no marked differences in the food composition between males and females of $L$. vannamei respectively.

However the analysis of the gut contents in respect of the different size groups show significant change in the food and feeding habits of $L$. vannamei at different stages of growth. The major portion of the diet of the shrimps examined consisted of animal tissue, although vegetable matter was found in small quantities in some of the guts [24]. Thomas (1980) remarked that Penaeus semisulcatus preferred meat of small animals such as nematodes, polychaetes, molluscs and crustaceans and is cannibalistic as are many other crustaceans [9]. The study on food and feeding habits of the L. vannamei showed that they mainly depended on animal food items and were carnivorous, irrespective size and sex in pond culturing conditions. Animal origin food given as foods leads to better growth in L. vannamei. The high quantities observed both phytoplankton and zooplankton in the guts and remarked that the species occasionally fed at the bottom. It's also in higher size groups, more often ingested crustaceans, mollusca, detritus, in large quantities than those in lower size groups. In the large size groups indicates that larger shrimp feed as for the supplementary feed very close to or near the bottom feeding on actively moving organisms. Although polychaetes and nematodes are not highly preferred food items, their higher grading in lower size groups. Mostly the cultured species appear to be opportunistic feeders, consuming a large diversity of preys and results from this study indicate that the $\mathrm{L}$.vannamei is non-selective opportunistic feeders. The previously noted that penaeid prawns are not selective in their feeding [25]. These observations also suggest that as the shrimp grow to larger size, the feeding spectrum of the species narrows down to a very few number of organisms of larger size. Hence the result of the present study that the most suitable food for L.vannamei for cultivable purposes should be a combination of crustaceans such as acetes sp, prawn, small crabs etc., mollusc, annelids and suggests that the pelletised feed consisting equal quantity of protein contents. The present investigation suggests that the nature food of the species is size dependent and it is obvious that comosition and preference of food is the same in both sexes. But observations on average amount of feeding in both sexes show that males exhibit a little higher feeding intensity than females. Therefore this study provides information one important aspect of the biology of any species which relevant to the success of any aquaculture operation is knowledge of its food and feeding habit. The nature and amount of food the organism takes in, the time of feeding, the effect of various environmental factors on its feeding behaviour and the relationship between feeding activity and onset of gonadal maturation are some of the information needed to achieve optimum utilization of the food given to the organism being cultured.

\section{References}

1. Lightner DV (1996) A Handbook of Shrimp Pathology and Diagnostic Procedures for Diseases of Cultured Penaeid Shrimp. The World Aquacult Soc 304.
2. Flegel TW (1997) Major viral diseases of the black tiger prawn (Penaeus monodon) in Thailand. World J Microbiol Biotechnol 13: 433-442.

3. FAO (Food and Agriculture Organization of the United Nations) (2007) Yearbook of Fisheries Statistics 2007. In: FAO Fisheries and Aquaculture Department. Food and Agriculture Organization of the United Nations, Rome.

4. Briggs M, Funge-Smith S, Subasinghe R, Phillips M (2004) Introductions and Movement of Penaeus vannamei and Penaeus stylirostris in Asia and the Pacific. In: FAO Regional Office for Asia and the Pacific, Bangkok, Thailand.

5. Liao IC, Chien YH (2011) The Pacific White Shrimp, Litopenaeus vannamei, in Asia: The world's most widely cultured alien crustacean. Invading Nature Springer Series in Invasion Ecol Spr Stut Technol 489-519.

6. Wyban J (2002) White shrimp boom continues. Glob Aquacult Adv 18-19.

7. Menon MK (1951) The life-history and bionomics of an Indian penaeid prawn Metapenaeus dobsoni (Miers). Proc Indo Pacif Fish Carnc 3: 80-93.

8. Thomas M (1972) Food and feeding habits of Penaeus monodon Fabricius from Korapha estuary. Indian J Fish 2: 202-204.

9. Thomas M (1980) Food and feeding habits of Panaeus semisulmtus de Haan at Mandapam. Ind J Fisher 27: 130-139.

10. Manoharan J, Gopalakrishnan A, Varadharajan D, Thilagavathi B, Priyadharsini S (2012) Stomach content analysis of Terapon jarbua (Forsskal) from Parangipettai coast, South East Coast of India. Advan Appl Sci Res 3 : 2605-2621.

11. Priyadharsini S, Manoharan J, Varadharajan D, Subramaniyan A (2012) Interpretation on the food and feeding habits of Dascyllus trimaculatus (Ruppell, 1829) from Gulf of Mannar, South East coast of India. Arch Appl Sci Res 4: 1758-1762.

12. Pillay TVR (1952) A critique of the method of study of food of fishes. Zool Soc India 4: 195-200.

13. Williams MJ (1981) Methods for analysis of natural diet in portunid crabs (Crustacea: Decapoda: Portunidae). J Exp Mar Biol Ecol 52: 103-113.

14. NIO (2004) Phytoplankton Identification Manual by Verlencar, X.N. and S.R Desai, Somshekar.National Institute of Oceanography. Dona Paula, Goa. Citation: 40.

15. Kasthurirangan LR (1963) A key for the identification of the more common plankton copepoda of Indian coastal waters. Coun Sci Indus Res 87.

16. Wickstead JH (1965) An introduction to the study of tropical zooplankton. In: Hutchinson Tropical Monographs, London, 160.

17. Fauvel P (1927) Polychetes Sedentaires \& Addenda aux Polychetes Errantes Faune de France. Federation Française des Societes de Science Naturel 16 1-494.

18. Berkeley (1952) Annelida, Polychaeta sedentaria. Canadian Pacific Fauna, Fish. Res. Bd, Canada, 9b (2): 1-139.

19. Albertoni EF, Palma-Silva C, Esteves F (2003) Natural diet of three species of shrimps in a tropical coastal lagoon. Braz Arch Biol Technol 46: 395-403.

20. Rao (1988) Studies on the feeding biology of Mebpenaeus mimxeros (Fabricius) along the Kakinada coast. J Mar Biol Ass India 30: 171-181.

21. Bello-Olusoji OA, Balogun AM, Fagbenro OA, Ugbaja N (1995) Food and feeding studies of the African river prawn Macrobrachium vollenhovenii. (Herklots, 1857). European Aquacult Soc Spl Pub 24: 425-427.

22. George MJ (1974) The food of the shrimp Metapenaeus monoceros (Fabricius) caught from the backwaters. Ibid 21: 495-500.

23. Tiews K, Bravo SA, Ronquillo IA (1968) On the food and feeding habits of some Philippine shrimps in Manila Bay and San Miquel Bay. Proc Indo-Pacific Fish Coun 13: 85-92.

24. Roy D, Singh SR (1997) The food and feeding habits of a freshwater prawn Macrobrachium choprai. Asi Fish Sci 10: 51- 63.

25. Abby-Kalio, N.J., 1990. Feeding and predation in penaeid shrimps of the Bonny and New Calabar estuaries of the Niger Delta. Paper presented at the 8th Annual Conference of the Fisheries Society of Nigeria, Akure. 